\title{
FREEDOM OF CITIZENS IN THE CONDITIONS OF MILITARY SERVICE
}

\section{Chebotareva G. V.}

\section{INTRODUCTION}

In the process of building the rule of law in Ukraine, perhaps the most important place is occupied by the solution of the problem of realization and protection of human and civil rights and freedoms. There is a reformation of all state institutions, bringing them into line with the provisions of the Basic Law.

In the context of reforming the Armed Forces, compliance with the legislation on universal military duty, military service and the legal status of servicemen, their social and legal protection, becomes important. The Constitution of Ukraine defines the fundamental principles in the field of human and civil rights and freedoms. "Human rights and freedoms and their guarantees, as stated in article 3 of the Basic Law, determine the content and direction of the state. The state is responsible to the person for its activities. The affirmation and enforcement of human rights and freedoms is the primary responsibility of the state." Therefore, the legal basis for military service must fully ensure the implementation of the rights and freedoms of the individual and citizen by military personnel. The serviceman should be perceived not only as a subject, but as an object of national security. Illegal and unlawful restriction of his rights and freedoms is inadmissible ${ }^{1}$.

A soldier should be perceived primarily as a citizen in uniform. After the perception and, accordingly, the disclosure of this topic is possible subject to a deep understanding and awareness by the servicemen themselves and the public of the essence of ensuring, implementing and protecting human rights and freedoms in the conditions of military service, the peculiarities of the legal status of servicemen, the legitimacy of establishing certain restrictions for them.

This section is not intended to disclose the content of all human and civil rights and freedoms in military service. It should be noted that the absolute majority of them, taking into account the Constitution and laws of Ukraine, fully applies to military personnel as equal members of civil society. At the same time, awareness of the principles and structure of the legal status of

\footnotetext{
${ }^{1}$ About economic activity in Armed Forces of Ukraine: the Law of Ukraine of 21.09.1999 No. 1076-XIV. URL: http://zakon1.rada.gov.ua/laws/show/1076-14
} 
servicemen, which is based on rights, freedoms and obligations, will allow the reader to correctly interpret any legal norm that defines rights and obligations, and apply it in solving a specific life situation.

\section{The concept and legal basis of the legal status of military personnel in Ukraine}

The relations that arise between the state and the individual, the relationship between people are fixed by the state in a legal form - in the form of rights, freedoms and obligations, which in their totality represent the legal status of a person and a citizen.

The legal status of a person and a citizen can be characterized as a system of rights and obligations, which are enshrined in the Constitution and other legislative acts.

Rights and obligations are the original element of law. They not only fix certain standards of behavior that the state considers mandatory, useful, appropriate for the normal functioning of the social system, but also reveal the basic principles of relations between the state and the individual.

Legal status, the nature of rights and obligations as the key concepts of legal science are constantly in the spotlight of scientists. There are several approaches to determining the legal status of an individual. Some of them equate the notion "legal status of a person" and "legal status persons" include legal status such as citizenship, the General legal principles of the legal status, rights, freedoms and duties, guarantees of rights and freedoms, the corresponding legal provisions. According to another view, the concept of legal status should be limited to categories of rights and obligations, which makes it possible to define its structure more clearly.

Thus, we will talk about two concepts: the legal status (position) of the person and the legal status of the person (soldier).

\section{Characteristics of the main elements of the legal status of a person}

The distinction between the concepts of "legal status" and "legal status of a person" is certainly relative, but at the same time, in our opinion, convenient for disclosure and awareness of the topic. The main elements characterizing the legal status of a person as a whole may include citizenship, legal personality, legal responsibility, principles of legal status, legal interests of a person, directly legal norms that determine the legal status of a person. It is advisable to refer to a brief description of the main of these elements.

Citizenship is a special political and legal relationship between a person and the state, which gives a person a special status, which implies legal recognition of the state affiliation of a person both in the country and abroad 
and gives him a full range of rights and obligations enshrined in the legislation of the state.

From the definition it is obvious that citizenship is one of the determining prerequisites of the legal status of a person, indicates the difference between the concepts of the legal status of a person and the legal status of a citizen. For the first time, the distinction between these concepts at the legislative level was recorded in the French Declaration of human and civil rights in 1789. It should be noted that the scope of the rights and obligations of a citizen is large, compared with the rights and obligations of a person. In particular, we note that the universal military duty in Ukraine applies only to its citizens ${ }^{2}$.

But according to the Constitution in our state there is a single citizenship. Therefore, there are no difficulties with the spread of universal military duty of its citizens, the passage of military service. However, a certain number of States recognize "dual citizenship". Naturally, under such conditions, it becomes more difficult to resolve the issue of military service by persons with dual citizenship. It is also obvious that the solution of this issue goes beyond the national legislation. In such cases, the provisions of the European Convention "on the reduction of cases of multi-citizenship and military duty" (1963) apply. In international practice, the doctrine of "real" (or effective) communication is widely applied, according to which a person with dual citizenship performs military service in the state in whose territory she predominantly resides.

\section{Legal personality includes the concept of legal capacity and capacity}

Legal capacity is the ability of a person to have rights and bear legal obligations (comes from the moment of birth of a person).

Legal capacity is the ability of a person to perform legally significant actions, that is, through them (actions) to acquire and exercise rights, create obligations for themselves and perform them (full legal capacity comes from the moment a person reaches adulthood).

It is necessary to point out the difference between the concept of legal personality in the branches of public and private law. In the branches of private law (civil, family, labor) there is a fundamental legal equality of all subjects regardless of their status ${ }^{3}$.

${ }^{2}$ About the state guarantees of social protection of the military personnel who leave service in connection with reforming of Armed Forces of Ukraine, and members of their families: the Law of Ukraine of 15.06.2004 No. 1763-IV). URL: http://zakon2.rada.gov.ua/ laws/show/1763-15

${ }^{3}$ The criminal code of Ukraine of 05.04.2001 № 2341-III. URL: http://zakon2.rada.gov.ua/ laws/show/2341-14 
In the branches of public law (criminal, administrative, military), there is mainly legal subordination and subordination, that is, issues of competence of state bodies and officials, on the one hand, and on the other - the question of passive legal personality of subordinates and subordinates, their duties and responsibilities, which are derived from the acts of authorities and officials.

Thus, legal personality is one of the significant, mandatory elements of the legal status of a person and a necessary prerequisite for its legal status.

Legal responsibility - the imposition on a person by the authorized bodies of state power, officials of the duties to bear adverse consequences of personal, organizational or material nature in the case of an offense, the performance or improper performance of the relevant duties.

Legal interests of the person - certain benefits of material and nonmaterial nature, which are enshrined not only in specific legal regulations, but also in General principles of law.

In other words, the interest is not always fixed in the rights of the person. As a rule, it precedes rights and obligations regardless of whether it is enshrined in law or simply subject to legal protection by the state.

The rights and obligations of the person have the corresponding normative fixing. This is what determines their legitimacy, the legitimacy of belonging to individual subjects. Therefore, it is reasonable to refer the relevant legal norms to the concept of the legal status of a person.

The principles of legal status are the fundamental ideas enshrined in the Constitution and other laws, the principles by which the rights, freedoms and duties of a person and a citizen are defined, as well as the guarantees of their implementation, and which transform the totality of individual rights and freedoms into a system.

Understanding of the legal nature of the principles of the legal status of a person is very important especially given the current provision of the Constitution of Ukraine on the rule of law (article 8 of the Constitution), the ability to apply the principle of analogy of law and the principle of analogy of law if there are gaps in the current legislation.

The basic principles of the legal status of a person include:

- Consolidation in national law of the rights and freedoms established by norms of international law.

- The principle of non-alienability and inviolability of the basic natural rights and freedoms of man and their belonging to him from birth (article 21 of the Constitution of Ukraine).

- The principle of equal rights and freedoms of persons (article 24 of the Constitution of Ukraine). This principle means that the exercise of human, civil rights, and freedoms must not violate the rights and freedoms of 
others. It proclaims the equality of all before the law and the court (part 3 of article 8 of the Constitution of Ukraine). The rights and freedoms of a person and a citizen are determined in the same way, regardless of sex, race, nationality, language, origin, place of residence, attitude to religion, etc. (part 3 of article 24 of the Constitution of Ukraine).

- The principle of unity of rights and duties of man and citizen (article 23 of the Constitution) is that there should not be rights without duties, as there should be no duties without rights. It is only in the process of fulfilling obligations that the rights that correspond to them are realized. In turn, the exercise of rights gives rise to certain obligations.

- The principle of guaranteeing human and civil rights and freedoms is that, firstly, constitutional rights and freedoms are guaranteed by the state and cannot be abolished, and, secondly, when new laws are adopted or amended, the content and scope of existing rights and freedoms cannot be narrowed.

- Guarantees of human, civil rights, and freedoms are a system of norms, principles, conditions and requirements that ensure the aggregate observance of the rights and freedoms of the legitimate interests of a person. This principle is one of the defining ones in the sphere of ensuring the realization and protection of rights and freedoms, and therefore requires a more complete disclosure of its content through the system of existing guarantees of rights and freedoms.

The system of guarantees of human rights and freedoms includes prerequisites of economic, political, organizational and legal nature, as well as protection of rights and freedoms. The system of guarantees is the conditions, means and methods ensuring the actual realization and comprehensive protection of the rights and freedoms of the individual ${ }^{4}$.

The practical realization of constitutional rights and freedoms is ensured by two criteria of guarantees. These are, first of all, General guarantees, which cover the whole set of objective and subjective factors aimed at the practical implementation of the rights and freedoms of citizens, the elimination of possible causes and obstacles to their incomplete or improper implementation, the protection of rights from violations. Secondly, these are special (legal) guarantees - legal bases and ways by means of which the rights and freedoms of citizens are realized, protected, protected, violations of the rights and freedoms are eliminated, the violated rights are restored.

General guarantees of rights and freedoms can be classified into economic, political and organizational.

\footnotetext{
${ }^{4}$ On international treaties of Ukraine: Law of Ukraine of 29.06.2004 No. 1906-IV). URL: http://zakon1.rada.gov.ua/laws/show/1906-15
} 
Economic guarantees of constitutional rights and freedoms of citizens of Ukraine are: the mode of production; the economic system of society, which should ensure the steady growth of productive forces on the basis of recognition and protection of various forms of ownership of the means of production; socially-oriented market economy; economic freedom of citizens and their associations in the choice of forms.

Political guarantees include: the state-the main organizer of the implementation and protection of human rights; the power of the people, which it exercises directly and through public authorities and local selfgovernment bodies; the right of citizens to freedom of Association in political parties and public organizations for the exercise and protection of their rights and freedoms; the right of citizens to participate in the management of state Affairs, in referendums, freely elect and be elected to public authorities and local self-government bodies; the right of citizens to apply for protection of their rights to the Commissioner of the Verkhovna Rada of Ukraine for human rights.

Organizational guarantees are systematic organizational activities of the state and all its bodies, officials and public organizations to create favorable conditions for the real enjoyment of their rights and freedoms.

Legal guarantees are the provision by the state of formal (legal) General obligation to those conditions that are necessary for everyone to be able to exercise their constitutional rights and freedoms. Legal guarantees are established by the state in the Constitution, norms of the current legislation. Their purpose is to provide real legal means of maximum implementation, protection and protection of constitutional rights and freedoms of citizens. In particular, the Basic Law provides for a number of specific guarantees, which are mainly traditional for the Constitution and laws of Ukraine. These include:

- the right to appeal in court the decisions, actions or omission of bodies of state power, bodies of local self-government, officials and officers;

- the right to compensation at the expense of the state or local selfgovernment bodies for material damage caused by illegal decisions, actions or omissions of these bodies and persons;

- the right to know their rights and obligations; laws and other regulatory legal acts that determine the rights and obligations of citizens, but are not brought to the attention of the population in the manner prescribed by laws, are invalid (article 57); inadmissibility of reverse action of the law is guaranteed ( no one can be responsible for acts that at the time of their);

- the right to legal assistance, which means, inter alia, that everyone is free to choose a defender of his rights, and in cases provided for by law, this assistance is provided free of charge (art. 59); 
- the principle of non-compliance with an obviously criminal order or order (art. 60);

- the principle of presumption of innocence, which means, inter alia, that a person is presumed innocent of a crime and cannot be subject to criminal punishment until his guilt has been proved legally and established by a court conviction, and that no one is obliged to prove his innocence of a crime (art. 62);

- the guarantee of inadmissibility of restriction of constitutional rights and freedoms means that these rights and freedoms cannot be limited, except for the cases provided by the Constitution of Ukraine (article 64).

The purpose of these and other legal guarantees contained in the Constitution and laws of Ukraine is to ensure favorable circumstances in which the status of a person and a citizen enshrined in the Constitution of Ukraine would become the legal and actual social status of each person. Guarantees, thus, are the link that allows for the necessary transition in the legal status of citizens from the possibility provided for in the Constitution and laws of Ukraine to reality.

\section{Normative regulation of the legal status of servicemen. Types of rights and obligations}

Given the above, we will also distinguish between the legal statuses of the individual servicemen in Ukraine in General and in particular its legal status, exclusively as a system of rights, freedoms and duties. In accordance with the legislation of Ukraine (the Law of Ukraine "on legal and social protection of servicemen and members of their families", the Statute of the internal service of the armed forces of Ukraine), servicemen are endowed with the full rights and freedoms and duties of citizens of Ukraine, cannot be limited in rights, except for cases expressly provided by law. At the same time, in the conditions of military service, citizens enter into special legal relations, they are assigned additional duties, and they are endowed with appropriate rights 5 .

To date, there are certain difficulties in the regulatory regulation of the rights, freedoms and duties of military personnel, there is no separate legal act, where they would be presented in a consolidated form. It is offered to Orient in a number of the relevant normative legal acts by means of the following conditional classification of the rights, freedoms and duties of the military personnel.

\footnotetext{
${ }^{5}$ About social and legal protection of the military personnel and members of their families: the Law of Ukraine of 20.12.1991 No. 2011-XII P. URL: http://zakon4.rada.gov.ua/ laws/show/2011-12
} 
First, these are General rights and obligations, which in turn are divided into civil, political, personal, socio-economic, cultural (they are disclosed in the previous sections). These rights and obligations are disclosed in international documents, agreements (international bill of human rights, European Convention for the protection of human rights and fundamental freedoms), the Constitution and laws of Ukraine.

Secondly, these are special rights and obligations.

They are most fully set out in the military statutes of the Armed Forces of Ukraine and some other legislative acts (for example, the Law of Ukraine "on General military duty and conscription"). It should be noted that in the Law of Ukraine "On universal military duty and military service" military service is defined as the state service of special nature and all the time the person in military service shall count towards the length of service.

And finally, third, these are special rights and obligations.

These may include certain restrictions that in accordance with the Constitution of Ukraine and the laws of Ukraine may be established in relation to the military, as well as benefits that must be considered as a kind of compensation for the restriction.

With regard to the legal regulation of this type of rights and obligations, it is necessary to note first the laws of Ukraine "on the Armed Forces of Ukraine", "on social and legal protection of servicemen and members of their families".

Thus, under the legal status of the soldier should understand the system of the rights and freedoms of man and citizen enshrined in the Constitution and other legislation, as well as special rights and obligations that arise in connection with military service.

The principle of combining the rights and freedoms and duties of a person, a citizen and a military person in the person of a serviceman is fundamental for determining his legal status, fully corresponds to the constitutional and legal bases for ensuring human rights and freedoms and in our opinion should be put at the center of all reform reforms in the sphere of military construction.

\section{Features of the legal status of military personnel}

The fundamental principle of the legal status of the serviceman is the inviolability of his status as a person and a citizen. "No one has the right to restrict military personnel in the rights and freedoms defined by the legislation of Ukraine", - stated in article 2 of the Law of Ukraine" on social and legal protection of military personnel and members of their families". Article 18 of the Charter of the internal service of the Armed Forces of 
Ukraine notes that "servicemen are protected by the state and have full rights and freedoms enshrined in the Constitution of Ukraine".

Regarding the legal status of servicemen, the provisions of article 22 of the Constitution of Ukraine apply: "the Rights and freedoms of man and citizen enshrined in this Constitution are not exhaustive. Constitutional rights and freedoms are guaranteed and cannot be revoked. When adopting new laws or amending existing laws, the content and scope of existing rights and freedoms shall not be restricted."

In our opinion, the modern legislative practice of the state is not quite consistent. Thus, the suspension of the legislation of Ukraine in terms of the benefits provided for the military by the laws of Ukraine on the state budget for 2000 (article 62) and for 2001 (article 58) comes into conflict with article 22 of the Constitution of Ukraine and therefore requires a minimum of official interpretation of this article of the Constitution and laws on the state budget in the necessary part.

We proceed from the fact (it was mentioned above) that part of the legal status of a serviceman is his special rights and obligations arising in connection with the passage of military service ${ }^{6}$.

Article 9 of the Charter of the internal service of the Armed Forces of Ukraine contains the following provision "Servicemen of the Armed Forces of Ukraine shall enjoy the rights and freedoms of citizens of Ukraine, taking into account the peculiarities determined by the Constitution of Ukraine, laws of Ukraine on military issues, military statutes of the Armed Forces of Ukraine and other legal acts".

The acts of legislation, military statutes, advisers, etc. define the special duties of the military. Comparing the relevant aspects of the legislation of the USSR and modern legal acts of Ukraine, we can conclude that a certain step forward is in terms of ensuring basic human rights and freedoms in military service. Thus, in the Charter of the internal service of the armed Forces of the USSR, the duties of servicemen included the following: "nothing, not even the threat of death, can force a soldier to surrender". In other words, the natural right of man to life was not recognized. Nothing of the kind is contained in the military statutes of the Armed Forces of Ukraine. Moreover, «the soldier is obliged to know and steadily observe the norms of international humanitarian law accepted by Ukraine". (article 15 of the Charter of the internal service of the Armed Forces of Ukraine). In accordance with international humanitarian law, prisoners of war are protected as victims of armed conflict and are subject to the relevant

\footnotetext{
${ }^{6}$ About Military service of a law and order in Armed Forces of Ukraine: the Law of Ukraine of 07.03.2002 No. 3099-III. URL: http://zakon4.rada.gov.ua/laws/show/3099-14
} 
provisions of the Geneva conventions for the protection of victims of war of 1949 and the two Additional protocols thereto of 1977. It can be concluded that servicemen of the Armed Forces of Ukraine, although this is not explicitly stated in the regulations, have the right to be captured. And this is a kind of form (carrier) of realization (provision) of the inalienable human right to life.

The peculiarity of the legal status of a serviceman is the establishment of certain restrictions in the rights and freedoms, the peculiarity of the implementation of certain rights and freedoms ${ }^{7}$.

In accordance with the legislation of Ukraine, political activity in the Armed Forces is limited. Military personnel stop membership in political parties and trade unions for the period of military service.

Military personnel can be members of public associations, except associations, statutory provisions which are contrary to the principles of the Armed forces of Ukraine, and may participate in their work in free from military duties when they are considered as such that do not fulfill military duties.

The organization of military strikes and participation in their conduct is not allowed.

Military personnel and employees of the Armed Forces of Ukraine may be restricted in freedom of movement, free choice of place of residence and the right to freely leave the territory of Ukraine, the right to collect, use and disseminate information in accordance with the law.

Employees of the Armed Forces of Ukraine suspend membership in political parties for the period of work in the Armed Forces of Ukraine.

The functioning of trade unions of employees who have concluded an employment contract with the Armed Forces of Ukraine is carried out in accordance with the Law of Ukraine "on trade unions, their rights and guarantees of activity".

Organization of strikes by employees of the Armed Forces of Ukraine and participation in their conduct are not allowed.

Every soldier is guaranteed the right to profess any religion or not to profess any.

Servicemen are given the opportunity to individually or collectively perform religious cults and rituals, conduct religious activities in compliance with the requirements of the Constitution of Ukraine and the laws of Ukraine.

7 On public procurement: Law of Ukraine of 10.04.2014 No. 1197-VII). URL: http://zakon2.rada.gov.ua/laws/show/1197-18 
At the same time, military personnel are guaranteed basic political and civil rights. Military personnel-citizens of Ukraine who serve in Ukraine, take part in all-Ukrainian and local referendums, elect and can be elected to the Verkhovna Rada of Ukraine, regional, district councils, other elected state bodies according to the Constitution of Ukraine

They are subject to the provisions of the Law of Ukraine "on elections of the President of Ukraine".

To the military personnel who stand candidates for people's deputies, their commanders (chiefs) have to create appropriate conditions for implementation of this right.

Military personnel elected to Councils or appointed to bodies formed by these Councils remain in military service and retain the status of military personnel. Soldiers, who are people's deputies, released from duty in connection with election to the authorities of the respective Councils, and not expressed a desire to retire to the reserve, comment to these Tips leaving for military service in the order established by the Cabinet of Ministers of Ukraine. The term of service in the Soviets or their bodies shall be counted in the total and continuous length of military service. After the end of the term of office of the Council of people's deputies and its bodies, the soldier goes to a military formation, where he served until the election for further service on positions not below that which he held until election to an elective office in the Council ${ }^{8}$.

Military personnel have the right to establish their public associations in accordance with the legislation of Ukraine. Military personnel may not be members of any political parties or organizations or movements. The organization of military strikes and participation in their conduct is not allowed.

Military personnel have the right to appeal to court illegal actions of military officials and bodies of military management.

Military personnel have an equal right to travel abroad with all citizens of Ukraine.

The last provision requires clarification. In accordance with the Constitution of Ukraine, everyone who legally resides on its territory is guaranteed freedom of movement, free choice of place of residence, the right to freely leave the territory of Ukraine, except for restrictions that are established by law. In accordance with article 17 of the Law of Ukraine "on the Armed Forces of Ukraine" servicemen may be restricted in freedom of movement.

\footnotetext{
${ }^{8}$ About bases of internal and foreign policy: the Law of 01.07.2010 No. 2411-VI. URL: http://zakon1.rada.gov.ua/laws/show/2411-17
} 
Article 216 of the Charter of the internal service of the Armed Forces of Ukraine establishes the following order of movement of servicemen. Conscripts in their spare time and work have the right to move freely on the territory of the military unit, and when dismissed - within the garrison. Departure of officers, warrant officers (midshipmen), the military personnel passing military service under the contract, outside of garrison is carried out with the permission of the commander of military unit. Departure of conscripts outside the garrison (except in cases of departure on vacation or business trip) is prohibited.

In our opinion, the procedure of arrest of servicemen is not legitimate.

In accordance with the Disciplinary Charter of the Armed Forces of Ukraine the authorities of the corresponding commander, the chief, can arrest conscripts and military service under contract to the military rank of "Sergeant" (main the ship's petty officer). The Law of Ukraine "on approval of the Disciplinary Statute of the Armed Forces of Ukraine" makes a reservation that the provisions of article 9 of The international Covenant on civil and political rights and article 5 of the European Convention for the protection of human rights and fundamental freedoms do not apply to the arrest procedure.

It would be appropriate to cite the main provisions of international legal acts and the Constitution in this part.

Article 9, paragraph 1, of the international Covenant on civil and political rights.

Everyone has the right to liberty and security of person. No one shall be subjected to arbitrary arrest or detention. No one shall be deprived of his liberty except on such grounds and in accordance with such procedure as are prescribed by law.

Article 5, paragraph 1, of the European Convention for the protection of human rights and fundamental freedoms.

Everyone has the right to liberty and security of person. No person may be deprived of his liberty except in accordance with the procedure established by law.

Part 2 of article 29 of the Constitution of Ukraine.

No one may be arrested or detained except by a reasoned decision of the court and only on the grounds and in the manner prescribed by law.

It seems that the legislator in this case ignored the provision of its own Constitution. After all, no reservations can be made about the Constitution. If to consider that in relation to the arrested military personnel in cases defined by the Charter of garrison and guard services the weapon (Art. 202, 241 of the Charter of garrison and guard services) can be applied, then the situation needs to be corrected immediately. 
The scope of rights and duties of military personnel is different depending on the positions they hold and military ranks. Service relations are characterized by signs of subordination and subordination. Commanders (chiefs) have the right to give orders (orders), and subordinates are obliged to carry them out. The Constitution of Ukraine (article 60) States that no one is obliged to carry out clearly criminal orders or orders.

For the giving and execution of an obviously criminal order or order comes legal responsibility. But in the relations of subordination and subordination it is also necessary to distinguish the concept of legal and illegal, lawful and unlawful, criminal and delict orders. The nature of such a legal category as an order (order) is sufficiently fully analyzed in the monograph of K. Dyachuk.

In the course of military service, citizens of Ukraine exercise the constitutional right to work (article 43 of the Constitution of Ukraine). At the same time, they are forbidden to engage in entrepreneurial activities (article 8 of the Law of Ukraine "on social and legal protection of servicemen and members of their families"). The law does not allow the use of military personnel to perform tasks not related to military service.

In respect of citizens of Ukraine serving in the Armed Forces of Ukraine and other military formations, as well as members of their families, the state provides social protection and their legal protection. The legislation of Ukraine for persons undergoing military service or otherwise perform military duty establishes a number of benefits. Benefits in this case should be understood as certain advantages for obtaining material benefits provided to citizens of Ukraine in connection with the performance of General military duty and military service. The provision of benefits can be regarded as a kind of compensation for restrictions, for certain deprivations imposed on military personnel. The basic law establishing privileges for military personnel is the Law of Ukraine "On social and legal protection of military personnel and members of their families". Disclosure of the scope and content of specific subjective rights of servicemen to benefits requires separate coverage. Analyzing the features of the legal status, it is important to note that the subjective right of servicemen to benefits is a necessary element of it (status).

Thus, the following can be attributed to the peculiarities of the legal status of military personnel:

- special rights and duties are established by special acts of legislation, military regulations, orders, advisers, installations, instructions;

- restriction of political activity (prohibition of participation in strikes, participation in political parties); 
- restrictions on freedom of movement (article 17 of The law of Ukraine "on the Armed Forces of Ukraine", article 216 of the Charter of the internal service of the Armed Forces of Ukraine);

- encroachment on the freedom and inviolability of military personnel (arrest);

- dependence of the legal status on the position and military rank;

- prohibition to engage in business activities;

- subjective entitlement to benefits.

- special procedure for bringing to administrative and material responsibility;

- military personnel act as a special subject in the composition of war crimes (Chapter 11 of the Criminal code of Ukraine).

\section{CONCLUSIONS}

Thus, the understanding of the military personnel of the above issues, awareness of the nature of the legal status, will contribute to an active legal position, the desire to fully realize and, if necessary, to protect their rights, as well as to conscientiously perform their duties in military service.

\section{SUMMARY}

International standards of human rights and freedoms and military service. Constitutional guarantees of human rights and freedoms in Ukraine. Delineation of the concepts of legal status and legal status of the individual. The legal status of military personnel in Ukraine. Problematic issues of ensuring human rights and freedoms in military service. Military personnel as a subject and object of national security. Civilian control over the military sphere as one of the effective means of ensuring human rights during military service. Validity and legality of restrictions in the rights and freedoms in the conditions of military service. International experience in the field of ensuring the rights and freedoms of servicemen and the possibility of its use in Ukraine.

Characteristics of the system, mechanisms, means, bodies, organizations, persons for the protection of human rights. State means of protection of human rights. Judicial protection of human rights. General characteristics of the judiciary. Constitutional right to judicial protection. Civil proceedings. Appeal in court of decisions, actions and inaction of public authorities, local self-government, officials and officials. Appeal to the military court with a complaint against illegal actions of officials of military administration. Criminal proceedings. Protection of the rights of the suspect, the accused, the defendant, the victim. Constitutional Court Of Ukraine. Commissioner of the Verkhovna Rada for human rights. Administrative and legal forms of 
human rights protection. The right to appeal (complaint) and its implementation in the conditions of military service. Public organizations and protection of human rights. International instruments for the protection of human rights. Control bodies established under the UN Charter. United Nations Commission on human rights (1946). United Nations high Commissioner for human rights (1993). The mechanism of individual complaints. Problems of efficiency of activity of control bodies and functioning of control mechanisms. European Commission on human rights. European Court of human rights. Appeal to the European Court of human rights. OSCE monitoring activities on the implementation of States obligations in human rights. Non-governmental organizations for the protection of human rights.

\section{REFERENCES}

1. Constitution of Ukraine of 28.06.1996 No. 254k/96-BP. URL: http://zakon4.rada.gov.ua/laws/show/254\%D0\%BA/96-\%D0\%B2\%D1\%80

2. Code of Ukraine on administrative offences of 07.12.1984 № 8073-XII. URL: http://zakon3.rada.gov.ua/laws/show/80731-10

3. The code of administrative proceedings of Ukraine of 06.07.2005 № 2747-IV. URL: http://zakon2.rada.gov.ua/laws/show/2747-15

4. The criminal code of Ukraine of 05.04.2001 № 2341-III URL: http://zakon2.rada.gov.ua/laws/show/2341-14

5. Civil code of Ukraine of 16.01.2003 № 435-IV URL: http://zakon4.rada.gov.ua/laws/show/435-15

6. Economic code of Ukraine of 16.01.2003 No. 436-IV. URL: http://zakon0.rada.gov.ua/laws/show/436-15

7. About Armed Forces of Ukraine: The Law of Ukraine of 06.12.1991 No. 1934-XII. URL: http://zakon2.rada.gov.ua/laws/show/1934-12

8. About social and legal protection of the military personnel and members of their families: the Law of Ukraine of 20.12.1991 No. 2011-XIIP. URL: http://zakon4.rada.gov.ua/laws/show/2011-12

9. About defense of Ukraine: The Law of Ukraine of 06.12.1991 No. 1932-XII. URL: http://zakon2.rada.gov.ua/laws/show/1932-12

10. About alternative (non-military) service: The Law of Ukraine of 12.12.1991 No. 1975-XII. URL: http://zakon4.rada.gov.ua/laws/show/ 1975-12

11. About use of lands of defense: The Law of Ukraine of 27.11.2003 No. 1345-IV. URL: http://zakon2.rada.gov.ua/laws/show/1345-15

12. On military duty and military service: Law of Ukraine from 25.03.1992, No. 2232-XII of the URL: http://zakon2.rada.gov.ua/laws/ show/2232-12 
13. About Military service of a law and order in Armed Forces of Ukraine: The Law of Ukraine of 07.03.2002 No. 3099-III. URL: http://zakon4.rada.gov.ua/laws/show/3099-14

14. About economic activity in Armed Forces of Ukraine: The Law of Ukraine of 21.09.1999 No. 1076-XIV. URL: http://zakon1.rada.gov.ua/ laws/show/1076-14

15. About democratic civil control over the Military organization and law enforcement agencies of the state: The Law of Ukraine of 19.06.2003. No. 975-IV). URL: http://zakon2.rada.gov.ua/laws/show/975-15

16. About the state guarantees of social protection of the military personnel who leave service in connection with reforming of Armed Forces of Ukraine, and members of their families: the Law of Ukraine of 15.06.2004 No. 1763-IV). URL: http://zakon2.rada.gov.ua/laws/show/ 1763-15

17. About bases of internal and foreign policy: The Law of 01.07.2010 No. 2411-VI. URL: http://zakon1.rada.gov.ua/laws/show/2411-17

18. On public procurement: Law of Ukraine of 10.04.2014 No. 1197-VII). URL: http://zakon2.rada.gov.ua/laws/show/1197-18

19. On international treaties of Ukraine: Law of Ukraine of 29.06.2004 No. 1906-IV). URL: http://zakon1.rada.gov.ua/laws/show/1906-15

20. About mobilization preparation and mobilization: the Law of Ukraine of 21.10.1993 No. 3543-XII P. URL: http://zakon2.rada.gov.ua/ laws/show/3543-12

\section{Information about the author:} Chebotareva G. V.,

Doctor of law, Professor,

Professor at the Department of Administrative,

Criminal Law and Procedure, International University of Business and Law 37-A, 49 HGD str., Kherson, 73040, Ukraine 